\title{
PENETAPAN PASARWAJO SEBAGAI IBU KOTA KABUPATEN BUTON (2003-2017) ${ }^{1}$
}

\author{
Oleh \\ Andi Firman ${ }^{2}$, Ali Hadara ${ }^{3}$
}

\begin{abstract}
ABSTRAK: Subtansi penelitian ini mengacu pada tiga aspek permasalahan dasar 1) Mengapa Pasarwajo ditetapkan sebagai Ibu Kota Kabupaten Buton? 2) Apa tantangan yang dihadapi dalam penetapan Pasarwajo sebagai Ibu Kota Kabupaten Buton? 3) Bagaimana perkembangan Pasarwajo sebagai Ibu Kota Kabupaten Buton?
\end{abstract}

Adapun tujuan dalam penelitian adalah: 1) Untuk mendeskripsikan latar belakang penetapan Pasarwajo sebagai Ibu Kota Kabupaten Buton. 2) Untuk mendeskripsikan tantangan yang dihadapi dalam penetapan Pasarwajo sebagai Ibu Kota Kabupaten Buton. 3) Untuk mendeskripsikan perkembangan Pasarwajo sebagai Ibu Kota Kabupaten Buton.

Metode yang digunakan dalam penelitian ini adalah metode penelitian sejarah menurut Helius Sjamsuddin, dengan tata kerja terdiri dari tiga tahapan, sebagai berikut: 1) Heuristik (pengumpulan sumber). 2) Kritik sumber yakni langkah kedua dari pengumpulan data atau sumber. 3) Historiografi (penulisan sejarah) yakni tahap akhir dari seluruh rangkaian kegiatan penelitian.

Hasil penelitian ini menunjukan bahwa: 1) Penetapan Pasarwajo sebagai Ibu Kota Kabupaten Buton berdasarkan peraturan pemerintah Republik Indonesia Nomor 29 tahun 2003 tentang pemindahan Ibu Kota Kabupaten Buton dari Kota Bau-Bau ke Pasarwajo di wilayah Kabupaten Buton. 2) Tantangan yang dihadapi dalam penetapan Pasarwajo sebagai Ibu Kota yaitu diantaranya konflik aset antara Kabupaten Buton dan Kota Bau-Bau serta penetapan lokasi Ibu Kota Kabupaten Buton antara Batauga dan Pasarwajo. Oleh karena itu berakhirnya konflik kedua wilayah ini tidak diikutkan sebagaimana yang diinginkan oleh masing-masing masyarakatnya melainkan berdasarkan bentuk wilayah yang baik untuk menjadi Ibu Kota, walaupun diketahui bahwa akan ada pihak-pihak yang mersa tidak adil tetapi hak dan wewenang diberikan kepada pemerintah untuk mengatur dan mengelolah suatu wilayah dan pengambilan keputusan khususnya dalam penetapan Ibu Kota Kabupaten Buton yang berada di wilayah Pasarwajo. 3) Perkembangan Pasarwajo sebagai Ibu Kota Kabupaten Buton mulai membenah dari segala aspek yaitu fasilitas pendidikan berdasarkan data tersebut ketersediaan sekolah setiap tahun cenderung bertambah. Serta jumlah fasilitas sekolah dan jumlah murid dan guru mulai dari tingkat pendidikan TK sampai SMA/SMK sederajat setiap tahun cenderung bertambah mulai dari guru sekolah dan murid sekolah. Kemudian fasilitas pasar berdasarkan data tersebut berbagai kegiatan perdagangan yang dilakukan di Kabupaten Buton seperti perdagangan ekspor-impor serta antar pulau semakin meningkat sarana perdagangannya. Fasilitas transportasi berdasarkan data menunjukan bahwa transportasi dalam penetapan Pasarwajo sebagai Ibu Kota Kabupaten Buton terus mengalami perkembangan, serta fasilitas pariwisata yang ada di Kabupaten Buton saat ini menjadi tujuan wisata dunia, pemerintah Kabupaten Buton terus meningkatkan fasilitas yang diinginkan wisatawan khususnya dibidang perhotelan dan wisatanya.

\section{Kata Kunci: Penetapan, Pasarwajo, dan Kabupaten Buton}

\footnotetext{
${ }^{1}$ Disadur dari hasil penelitian 2019

${ }^{2}$ Alumni pendidikan sejarah UHO, wisuda periode April 2019

${ }^{3}$ Dosen FKIP UHO
} 
E-ISSN: 2502-6674

P-ISSN: 2502-6666

http://ojs.uho.ac.id/index.php/p_sejarah_uho

\section{PENDAHULUAN}

Pemerintahan pada masa sekarang memiliki fungsi diantaranya memberikan pelayanan sesuai dengan aturan hukum yang berlaku dan memberikan pelayanan publik yang baik dan optimal (Rieseneder, 2008: 26). Pelayanan publik yang optimal menjadi salah satu faktor yang menentukan kepuasan pelayanan bagi masyarakat. Pemindahan pusat pemerintahan dalam konteks ini bukan diartikan sebagai pemindahan Ibukota, namun diartikan sebagai pemindahan salah satu fungsi ibukota yang sangat kompleks, yang salah satunya ialah fungsi pemerintahan. Pusat pemerintahan sendiri diartikan sebagai fungsi wilayah yang didalamnya mencakup perkantoran pemerintahan dan berbagai fasilitas penunjang lainnya untuk menjalankan kegiatan kepemerintahan.

Kebijakan pemindahan pusat pemerintahan dari satu wilayah ke wilayah yang lain menjadi sebuah keputusan yang besar, karena membutuhkan kesiapan institusi, masyarakat, dan dana yang cukup banyak. Memindahkan fungsi pemerintahan ke lokasi yang baru merupakan sebuah upaya pemerintah untuk membantu mengurangi tekanan di kota utama akibat berbagai permasalahan perkotaan dan memberikan ruang lebih seiring dengan meningkatnya kebutuhan akan lahan perkantoran. Dengan adanya pusat pemerintahan yang baru memungkinkan pemerintah membangun pusat perkotaan yang terencana dengan baik yang dilengkapi dengan berbagai fasilitas dan teknologi penunjang untuk meningkatkan efisiensi dan produktifitas pemerintah (Siong, H.C, 2006: 52).

Kemunculan kebijakan pemindahan pusat pemerintahan di Indonesia tak lepas dari Undang-Undang No. 22 Tahun 1999 tentang otonomi daerah yang pertama kali mengemukakan adanya kebijakan desentralisasi, dimana pemerintah daerah mendapatkan wewenang dalam mengatur urusan kepemerintahannya. Optimalisasi pelayanan pemerintah inilah yang menjadi dasar banyak pemerintah daerah di Indonesia membuat kebijakan untuk memisahkan fungsi pemerintahan dari kompleksitas fungsi ibukota, dengan harapan agar pelayanan dan sistem pemerintahan dapat berjalan lebih optimal.

Pada tahun 2001 salah satu daerah otonomi baru yang terbentuk adalah Kota Bau-Bau merupakan daerah hasil pemekaran dari Kabupaten Buton yang dibentuk dengan UU Nomor 13 Tahun 2001 tentang pembentukan Kota Bau-Bau. Kota Bau-Bau merupakan kota administratif yang berdiri pada tahun 1981 berdasarkan peraturan pemerintahan No. 40 Tahun 1981 tentang pembentukan kota admnistratif Bau-Bau (Darwin Tuwu, 2009: 45). Pembentukan daerah otonomi baru diantaranya yang ditempuh melalui pemekaran daerah. Pada saat yang bersamaan Kota BauBau di tingkatkan statusnya menjadi kota maka dari itu peraturan pemerintah kota administratif Bau-Bau dinyatakan sudah tidak berlaku lagi sehingga ibu kota yang dulunya di Bau-bau dipindahkan di Pasarwajo. Dengan demikian, terkait uraian di atas, penetapan Pasarwajo sebagai Ibu Kota Kabupaten Buton yang terjadi pada masyarakat Kabupaten Buton perlu diteliti lebih lanjut.

\section{METODE PENELITIAN}

\section{Jenis dan Pendekatan Penelitian}

Penelitian ini merupakan jenis penelitian sejarah. Kemudian Pendekatan yang digunakan dalam penelitian ini adalah pendekatan strukturis. Leirissa (2004: 4) menjelaskan fokus penelitian pendekatan strukturis tidak semata-mata pada struktur sosial, tetapi pada agency yang sanggup memilih alternatif untuk menggantikan struktur sosial yang menjadi bagian dari diri mereka sendiri. Pendekatan strukturis mencoba menentukan mengapa suatu struktur sosial bertahan lama/langgeng atau terjadi perubahan sosial.

\section{Sumber Data Penelitian}

Sumber data yang digunakan dalam penelitian ini terbagi atas tiga kategori yakni antara lain sebagai berikut; (1) Sumber tertulis, (2) Sumber lisan, dan (3) Sumber visual, keseluruhan data dikumpulkan selama 2 bulan yaitu Oktober s/d November 2018, dipusatkan di Pasarwajo . 


\section{Metode Penelitian}

Metode yang digunakan dalam penelitian ini yaitu mengadopsi pendapat Helius Sjamsuddin (2012: 85) yang meliputi lima tahapan yaitu: (1) Pemilihan topik, (2) Pengumpulan sumber, (3) Verifikasi (kritik sejarah, keabsahan sumber), (4) Interpretasi: analisis dan sintesis, (5) Penulisan (historigrafi). Penyusunan data merupakan bagian akhir dari seluruh rangkaian penelitian sejarah. Pada bagian ini penulis berusaha melakukan perpaduan kemampuan berpikir dengan kerja seni. Kemampuan berpikir sangat diperlukan pada saat peneliti melakukan kegiatan analisis dan sintesis terhadap informasi sejarah yang ada, berdasarkan data dan fakta yang berhasil dikumpulkan dan telah lulus verifikasi serta sudah diinterpretasikan.

\section{HASIL PENELITIAN}

\section{Latar Belakang Penetapan Pasarwajo sebagai Ibu Kota Kabupaten Buton}

Ibu Kota sebuah kabupaten pada dasarnya mempunyai multifungsi antara lain: sebagai pusat pemerintahan, pelayanan umum, permukiman, perdagangan dan jasa. Melalui berbagai fungsi ini, keterpaduan, keseimbangan dan kesinambungan perkembangan antar-wilayah di Kabupaten Buton serta keserasian antar sektor pembangunan diharapkan dapat diwujudkan.

Penentuan lokasi Ibu Kota bukanlah dilakukan dengan serta merta menunjuk lokasi tertentu, akan tetapi memerlukan kajian dan analisis dari berbagai kriteria dan indikator pertumbuhan dan perkembangan kota baik menyangkut faktor internal, faktor eksternal dan daya dukung lingkungan Ibu Kota baru. Kelayakan lokasi ibukota sebagai pusat pemerintahan juga harus mempertimbangkan faktor-faktor yang memungkinkan terjalinnya hubungan efektif antara pemerintah dan masyarakat, mampu mempertimbangkan segala kebutuhan ruang, pelayanan, dan aksesibilitas yang prima terhadap kelancaran roda pemerintahan.

Tentang penentuan lokasi obyek-obyek maupun tempat-tempat kegiatan berlangsung, dimaksudkan untuk mencapai efisiensi dan optimasi. Efisiensi dan optimasi yang dimaksud adalah dalam hal pengarahan menuju lokasi yang bersangkutan maupun dalam hal pengisian ruang. Ruang, yang menampung kegiatan-kegiatan manusia pada kenyataannya berbeda dalam kualitas dan karakteristiknya. Penggunaan yang efisien dan optimal berarti memilih dan menentukan kegiatan-kegiatan yang sesuai dan paling menguntungkan bagi suatu ruang tertentu pemilihan ini dipengaruhi oleh potensi yang dimiliki. Dengan sumber daya manusia yang berkualitas, daerah akan mampu untuk membuka peluang-peluang potensi yang terdapat pada daerah tersebut.

Sebelum Pasarwajo ditetapkan sebagai Ibu Kota Kabupaten Buton berdasarkan peraturan pemerintah Republik Indonesia Nomor 29 tahun 2003 tentang pemindahan Ibukota Kabupaten Buton dari wilayah Kota Bau-Bau ke Pasarwajo di wilayah Kabupaten Buton (Berdasarkan SK Pemindahan terlampir). Sebelum Kabupaten Buton beribu kota di Bau-Bau. Kota Bau-Bau merupakan daerah hasil pemekaran dari Kabupaten Buton yang dibentuk dengan Undang-Undang Nomor 13 Tahun 2001 (UU No. 13 Tahun 2001) tentang pembentukan Kota Bau-Bau.

Tanggal 21 Juni 2001, pemerintah menetapkan UU No. 13 Tahun 2001 tentang Pembentukan kota Bau-Bau dan dimuat dalam Tambahan Lembaran Negara Republik Indonesia Nomor 93 Tahun 2001. Dengan terbentuknya Kota Bau-Bau berdasarkan UU No. 13 Tahun 2001, maka Peraturan Pemerintah Kota Administratif Bau-Bau menjadi daerah otonom baru pada tanggal 21 Juni 2001 berdasarkan UU. No. 13 Tahun 2001, secara formal dan administratif, kota Bau-Bau telah punya wewenang untuk mengatur dan mengurus urusan rumah tangganya sendiri untuk memajukan daerah dan meningkatkan kesejahteraan daerah.

Jadi setelah Bau-Bau mejadi sebuah pemerintah berbentuk kota di pulau Buton, Sulawesi Tenggara. Terjadilah perdebatan tentang pemindahan lokasi Ibu Kota Kabupaten Buton yaitu antara Batauga dan Pasarwajo. Karena saat itu Bupati Buton tidak punya sikap dalam menentukan Ibu Kota yang baru tersebut, selain dua wilayah kecamatan yakni Pasarwajo dan Batauga diserahkan kepada pemerintah pusat yang menetapkan Ibu Kota Kabupaten Buton yang itu menjadi 
lambat dan baru ditetapkan Kecamatan Pasarwajo sebagai Ibu Kota Kabupaten Buton yang baru pada tanggal 10 Juni 2003 tentang pemindahan Ibu Kota Kabupaten Buton dari wilayah Kota BauBau ke Pasarwajo.

\section{Tantangan yang Dihadapi Dalam Penetapan Pasarwajo Sebagai Ibu Kota Kabupaten Buton}

Tantangan yang dihadapi dalam penetapan Pasarwajo sebagai ibu kota Kabupaten Buton diantarnya yaitu:

1. Konflik Aset antara Kabupaten Buton dan Kota Bau-Bau

Sejak jatuhnya rezim orde baru pada tahun 1998. Indonesia melalui penyelengaraan pemerintah yang lebih demokratis. Demokrasisasi tersebut membawa perubahan dalam sistem pemerintahan yang semula sentralistis menjadi desentralistis. Sejak runtuhnya Orde Baru memberi kewenangan lebih besar kepada daerah dan memberikan kewenangan lebih besar kepada daerah dalam memberikan otonomi seluas-luasnya kepada daerah untuk mengurus rumah tangga sendiri. Berbagai aspek dipertimbangkan dalam melakukan pemekaran daerah mulai dari pertimbangan kemampuan ekonomi, potensi daerah, sosial budaya, memungkinkan terselenggara otonomi daerah. Pada tanggal 21 Juni 2001 pemerintah menetapkan tentang peningkatan status koda administratif Bau-Bau menjadi daerah otonomi baru dan Bau-Bau telah punya wewenang untuk mengatur dan mengurus urusan rumah tangganya sendiri untuk memajukkan daerah dan meningkatkan kesejahteraan daerah.

Sejak pertama kali Kota Bau-Bau terpisah dari Kabupaten Buton telah memerintahkan bahwa segala bentuk aset Kabupaten Buton yang berada diwilayah kota Bau-Bau harus diserahkan. Konflik antara pemerintah Kabupaten Buton dengan pemerintah Kota Bau-Bau saling bertentangan terkait dengan penguasaan dan pengelolaan aset daerah yang berada dalam wilayah Kota Bau-Bau. Pemerintah kabupaten Buton selaku Kabupaten induk merasa mempunyai otoritas yang sah sementara pemerintah kota Bau-Bau selaku daerah hasil pemekaran. Konflik sebagai perselisihan yang disebabkan oleh adanyan perbedaan pendapat tentang kasus konflik aset yang telah berlangsung lama. Pemerintah Kabupaten Buton belum menyerahkan seluruh aset daerah kepada pemerintah kota Bau-Bau.

Penyerahan tersebut selambat-lambatnya 1 (satu) tahun. Konflik tersebut mempunyai implikasi terhadap pelayan publik. Masalah utama yang paling dirasakan oleh kedua pemerintah terutama pada masa-masa awal pemekeran tahun-tahun pertama pemekaran adalah ketidakcukupan fasilitas atau ketidaktersedianyaa sarana dan prasarana perkotaan dan perkantoran. Kedua pemda merasakan hal yang yang sama yaitu, kekurangan atau ketidakcukupan fasilitas sarana dan prasarana fasilitas dan sarana prasaran perkantoran. Pemkab Buton, pada awal-awal pemekaran masih melakukan pelayanan public di Kota Bau-Bau, hal tersebut disebabkan oleh karena sebagian besar kantor-kantor Pemkab Buton masih berada di Kota Bau-Bau dan bukanya dilakukan di Pasarwajo sebagai Ibu Kota Kabupaten Buton yang baru.

\section{Konflik Penetapan Ibukota Kabupaten Buton}

Sebelum ditetapkanya Pasarwajo sebagai Ibu Kota Kabupaten Buton terjadilah pertentangan tentang penetapan Ibu Kota antara Pasarwajo dan Batauga. Dilain pihak Batauga cocok untuk menjadi Ibu Kota Kabupaten Buton dari faktor sejarah dulu. Berangkat dari faktor sejarah yang diemban oleh masyarakat bermuara pada gerakan masyarakat untuk menuntut penempatan Ibu Kota Kabupaten Buton yang berada di Pasarwajo semestinya di Batauga.

Penyampaian aspirasi tuntunan dan gerakan masyarakat Batauga yang muncul pada tahun 2003. Sejumlah organisasi kemasyarakatan ikut terlibat dalam proses penyampaian aspirasinya. Tuntuntan didasarkan pada SK DPRD Kabupatrn Buton tentang Ibu Kota di Batauga. Pada tanggal 14 Agustus 1999 yang menetapkan daerah tingkat Kabupaten Buton berkedudukan di Batauga. Berdasarkan tuntutan masyarakat dari awal dari penempatan Ibu Kota kabupaten Buton masyarakat ingin menuntuk ketidakadilan apa yang melandasi kenapa harus keputusan DPRD Batauga mengapa harus di pindahkan di Pasarwajo. 
E-ISSN: 2502-6674

P-ISSN: 2502-6666

http://ojs.uho.ac.id/index.php/p_sejarah_uho

\section{Perkembangan Pasarwajo Sebagai Ibu Kota Kabupaten Buton}

Perkembangan Pembangunan di Kabupaten Buton perlu diimbangi dengan peraturan tata ruang wilayah khususnya bagi pusat pemerintah/Ibu kota Kabupaten Buton, salah satu upaya yang dilakukan adalah pemindahan Ibu Kota Kabupaten Buton selaku pusat pemerintahan dan pembangunan yang masih berada di Wilayah kota Bau-Bau ke Pasarwajo. Sejalan dengan itu tentang pemindahan Ibu Kota, Pasarwajo sebagai Ibukota Kabupaten Buton mulai membenah dari segala aspek di antaranya yaitu:

1. Fasilitas Pendidikan

Keberhasilan pembangunan pendidikan bagi suatu daerah merupakan salah satu Indikator keberhasilan pembangunan secara keseluruhan. Hal tersebut disebabkan masalah pendidikan mendapat perhatian khusus dari pemerintah. Pemeberian anggaran sebesar $20 \%$ pada urusan pendidikan diharapkan mampu mendongkrak kekuranan-kekurangan dalam bidang tersebut. Olehnya itu keberhasilan pendidikan tentu tidak terlepas dari peran keberadaan fasilitas dan perangkat pendukung didalamnya. Perbandingan keberadaan fasilitas yang memadai dan ketersediaan yang sumber daya yang ada perlu mendapat perhatian pula. Olehnya iu rasio ketersediaan Sekolah merupakan perbandingan jumlah sekolah yang ada di Kabupaten Buton untuk setiap jenjang pendidikan dengan jumlah kelompok belajar siswa.

2. Fasilitas Pasar

Pasarwajo juga merupakan pusat administrasi dan ibu kota kabupaten. Pasarwajo terletak di pesisir timur Pulau Buton dan merupakan salah satu pelabuhan penting di Sulawesi Tenggara. Pasarwajo memiliki peranan yang besar di wilayah Kabupaten Buton. Selain pusat pemerintahan, Pasarwajo juga merupakan sebuah kota pariwisata yang ada di kabupaten ini. Pasarwajo juga memiliki beragam pusat perdagangan dan perbelanjaan. Beragam industri laut juga bisa ditemukan di sini. Inilah mengapa kota ini disebut dengan nama Pasarwajo.

Kegiatan perdagangan di Kabupaten Buton terdiri dari perdagangan ekspor dan impor serta perdagangan antar pulau. Pada perdagangan ekspor, jenis barang yang diperdagangkan meliputi berbagai komoditas dari hasil pertambangan, perikanan. Sedangkan pada kegiatan impor, barang yang diimpor yaitu barang modal dan barang elektronik.

3. Fasilitas Transportasi

Penetapan Pasarwajo sebagai Ibu kota Kabupaten Buton berbagai perkembangan dapat kita lihat, apabila menuju Kabupaten Buton, kita bisa menggunakan jasa beberapa maskapai antara lain Garuda Indonesia, Lion Air, Batik Air, atau Wings Air ke Bandara Betoambari di Kota Bau-Bau. Rata-rata penerbangan menuju Buton harus transit dari Makassar atau Kendari. Dari Bandara Betoambari, perjalanan dilanjutkan dengan transportasi darat selama satu jam menuju Pasarwajo yang merupakan pusat dari Kabupaten Buton.

Jalan merupakan prasarana angkutan darat yang sangat penting dalam memperlancar kegiatan hubungan perekonomian, baik antara satu kota dengan kota lainnya, maupun antara kota dengan desa dan antara satu desa dengan desa lainnya. Kondisi jalan yang baik akan memudahkan mobilitas penduduk dalam mengadakan hubungan perekonomian dan kegiatan sosial lainnya.. sarana angkutan darat seperti kendaraan bermotor disamping dapat dipergunakan oleh masyarakat sebagai angkutan penumpang, juga dapat dipergunakan sebagai angkutan barang-barang produksi hasil pertanian, kehutanan, dan hasil-hasil lainnya.

\section{KESIMPULAN}

Adapun kesimpulan yang dapat ditarik dan menjadi catatan akhir dari ringkasan penelitian ini yaitu: pertama penetapan Pasarwajo sebagai Ibu Kota Kabupaten Buton berdasarkan peraturan pemerintah Republik Indonesia Nomor 29 tahun 2003 tentang pemindahan ibukota Kabupaten Buton dari wilayah Kota Bau-Bau ke Pasarwajo di wilayah Kabupaten Buton. Untuk mengurangi ketimpangan dalam pembangunan maka setiap pembangunan atau perubahan menghendaki adanya penetapan. Dengan terbentuknya kota Bau-Bau maka pemerintah Kabupaten Buton harus memindahkan Ibu Kotanya. Saat itu sempat terjadi polemik yang berkepanjangan karena masyarakat Buton memiliki ususlan yang berbeda. Terjadilah perdebatan tentang pemindahan 
lokasi ibukota Kabupaten Buton yaitu Batauga dan Pasarwajo. Keputusan diserahkan kepada pemerintah pusat yang menetapkan Ibu Kota Kabupaten Buton yang baru, dan pada tanggal 10 juni 2003 tentang pemindahan Ibu Kota Kabupaten Buton dari wilayah kota Bau-Bau ke Pasarwajo.

Kedua Tantangan yang dihadapi dalam penetapan Pasarwajo sebagai Ibu Kota yaitu diantaranya konflik aset antara Kabupaten Buton dan Kota Bau-Bau serta penetapan lokasi Ibu Kota Kabupaten Buton antara Batauga dan Pasarwajo. Berbagai aspek dipertimbangkan dalam melakukan pemekaran daerah mulai dari pertimbangan kemampuan ekonomi, potensi daerah, sosial budaya, memungkinkan terselenggara otonomi daerah. Pada masa-masa awal pemekeran tahun-tahun pertama pemekaran adalah ketidakcukupan fasilitas atau ketidaktersedianyaa sarana dan prasarana perkotaan dan perkantoran. Pada awal-awal pemekaran masih melakukan pelayanan publik di kota Bau-Bau, hal tersebut disebabkan oleh karena sebagian besar kantor-kantor Pemkab Buton masih berada di Kota Bau-Bau dan bukanya dilakukan di Pasarwajo sebagai Ibu Kota Kabupaten Buton yang baru. Penyampaian aspirasi tuntunan dan gerakan masyarakat Batauga yang muncul Sejumlah organisasi kemasyarakatan ikut terlibat dalam proses penyampaian aspirasinya. Tuntuntan didasarkan pada SK DPRD Kabupaten Buton tentang Ibu Kota di Batauga. Berdasarkan tuntutan masyarakat dari awal dari penempatan Ibu Kota kabupaten Buton masyarakat ingin menuntuk ketidak adilan yang melandasi kenapa harus keputusan DPRD Batauga mengapa harus di pindahkan di Pasarwajo.

Ketiga Sebagai salah satu kawasan strategis dalam bidang perikanan, pertanian dan parawisata, harus bisa dimaksimalkan oleh Pasarwajo Ibu Kota Kabupaten Buton untuk menjadi daerah otonom yang mapan dan mandiri. Perbaikan sarana dan prasarana jalan raya, perkantoran, dan fasilitas umum sebaiknya menjadi prioritas utama, agar aktivitas pengangkutan perikanan, pertanian dan daya tarik parwisata lebih bisa optimal dan memberikan pendepatan yang bisa memberikan kesejahteraan bagi masyarakatnnya.

\section{DAFTAR PUSTAKA}

Darwin Tuwu. 2009. Konflik Aset Daerah Dalam Pemekaran Wilayah (Studi Tentang Konflik Kepemilikan Bangunan Antara Pemerintah Kabupaten Buton dengan Pemerintah Kota BauBau) Tesis. Yogyakarta: UGM.

Helius Sjamsuddin. 2012. Metodologi Sejarah. Yogyakarta: Ombak.

Siong. H.C. 2006. Putrajaya-Administrative of Malaysia: Planing, Concept, and

Implementation. Suistanaible Urban Development and Goverance Conference SungKyunkwan University Seoul.

Surat Keputusan, 2007 "Penetapan Hari Jadi Pasarwajo Sebagai Ibu Kota Kabupaten Buton."

Surat Keputusan, 2003 "Pemindahan Ibu Kota Kabupaten Buton Dari Wilayah Kota Bau-Bau Ke Pasarwajo Di Wilayah Kabupaten Buton.

Monografi Kecamatan Pasarwajo, 2017'Keadaan Geografi"

Monografi Kecamatan Pasarwajo, 2017 "Data Penduduk Desa/Kelurahan Sekecamatan Pasarwajo" 